\title{
Weed Control in Field Nurseries
}

James E. Altland, ${ }^{1}$ Charles H. Gilliam, ${ }^{2}$ and Glenn Wehtje ${ }^{3}$

Summary. Herbicide use is an important component of weed management in field nursery crops. No single herbicide controls all weed species. Oxyfluorfen, simazine, and isoxaben are preemergence herbicides effective against broadleaf weeds. Oryzalin, pendimethalin, and prodiamine are effective in preemergence control of grasses and some small-seeded broadleaf weeds. Metolachlor is the only herbicide currently labeled for nursery crops that is effective in preemergence nutsedge (Cyperus) control. Fluazifop-butyl, sethoxydim, and clethodim are selective postemergence herbicides used for grass control. Glyphosate, paraquat, and glufosinate are nonselective postemergence herbicides used in directed spray applications for broad-spectrum weed control. Bentazon, halosulfuron, and imazaquin are effective postemergence nutsedge herbicides. These herbicides are discussed with respect to their chemical class, mode of action, labeled rates, and current research addressing their effectiveness in nursery crops.

W Teed control is an important component of producing quality field-grown nursery stock. Many field-grown crops are planted as small liners which take several years before reaching salable size. During this time nursery crops offer limited competition with weeds for nutrients and water. Research on herbicide application timing for field-grown plants suggests the need for weed control is greatest during the first year following planting (Wehtje and Gilliam, 1991). Though growth suppression by weed competition in field-grown nursery stock has not been documented, reduced shoot growth up the $43 \%$ has been documented in container stock (Berchielli-Roberston et al., 1990). In addition, weeds reduce the aesthetic value of nursery crops and may also serve as a source of weed inoculation in the landscape or host plants for insects.

Successful use of herbicides for weed control requires a three-step process. First, when applicable, weeds should be eliminated preplant using a broad-spectrum postemergence herbicide or soil sterilant. Cultivation could be an acceptable method for eliminating annual weeds, however, herbicides are more effective in controlling perennials or weeds with developed underground storage tissue. Second, occurrence of new weeds should be prevented using preemergence-applied herbicides. This should be the primary action taken to control weeds in nurseries, and thus will be the focus of this manuscript. And finally, escape weeds should be controlled using postemergence weed control methods.

\footnotetext{
${ }^{1}$ Assistant professor of horticulture, 15210 NE Miley Road, North Willamette Research and Extension Center, Oregon State University, Aurora, OR 97002

${ }^{2}$ Professor of horticulture, Department of Horticulture, 101 Funchess Hall, Auburn University, AL 36849

${ }^{3}$ Professor of agronomy, Department of Horticulture, 101 Funchess Hall, Auburn University, AL 36849.
} 


\section{Preemergence weed control}

Why HeRBICIDES FAIL. There are several reasons why herbicides are sometimes ineffective. The most common reasons include improper application timing, improper application rates, and not choosing the most effective herbicide for the prevalent weed species.

Preemergence-applied herbicides should be applied to weed free areas because they have little or no activity when applied to emerged seedlings. A major reason why these herbicides fail in field-grown nurseries is that they are applied when weeds have already germinated. Also, many of the herbicides currently used do not have sufficient residual activity to provide season long control from a single application (Wehtje and Gilliam, 1991). In the southeastern United Sates, most herbicides provide only 10 to 14 weeks of activity in the field (Gilliam, 1989). As the herbicidal barrier from an application begins to degrade, a follow-up application is needed before weed seed germination. Monitoring weed populations is essential to determine proper timing. In a test which evaluated the effects of application timing using various combinations of simazine (Princep; Syngenta Crop Protection, Greensboro, N.C.), oryzalin (Surflan; Dow AgroSciences, Indianapolis, Ind.) and oxyfluorfen (Goal; Dow AgroSciences), application timing was shown to be of greater importance than herbicide selection. Specifically, an application in March of any combination of two herbicides providing broadspectrum activity served to eliminate much of the weed competition during the period of spring growth, and a second application extended control through the remainder of the season (Wehtje and Gilliam, 1991). Also, rainfall or irrigation is necessary to activate most herbicides [ usually 0.5 inch ( 1.27 $\mathrm{cm}$ ) of precipitation, but may vary by herbicide]. Because many field-grown crops are not irrigated, application timing before precipitation is critical.

Identification of weed species is required in order to choose the most effective herbicides for controlling prevalent weed species. Even if specific identification cannot be made, the ability to differentiate between grass, broadleaf, and sedge species is critical in choosing the correct herbicide.

Broadleaf-active preemerGence herbicides. No single herbicide controls all weeds. Preemergence herbicides are typically classified as controlling either broadleaf, grass, or sedge species. It is common practice to combine a herbicide effective in controlling broadleaf species with another effective against grasses. Oxyfluorfen, simazine, and isoxaben (Gallery; Dow AgroSciences) are preemergence herbicides currently available to control broadleaf species in field nurseries (Table 1).

Oxyfluorfen, a diphenyl ether, is absorbed by foliage and root tissue where it inhibits protoporphyrinogen oxidase (also called protox) (Ross and Lembi, 1999). Oxyfluorfen is marketed for the nursery industry as Goal
2XL, an emulsifiable concentrate (EC) containing $2.0 \mathrm{lb} / \mathrm{gal}\left(0.24 \mathrm{~kg} \cdot \mathrm{L}^{-1}\right)$ a.i. (previous products were marketed as $2 \mathrm{E}$ and $1.6 \mathrm{E}$ formulations). Oxyfluorfen should be applied at 0.5 to $2.0 \mathrm{lb} /$ acre $\left(0.56\right.$ to $\left.2.24 \mathrm{~kg} \cdot \mathrm{ha}^{-1}\right)$, and all applications should not exceed more than $2 \mathrm{lb} /$ acre per year (C\&P Press, 2001). Oxyfluorfen provides excellent preemergence broadleaf weed control, but almost no control of grasses (Coffman et al., 1984; Coffman and Frank, 1987). In addition, it is one of the few preemergence herbicides with postemergence activity on newly emerged weeds. Fretz et al. (1980) compared the $2 \mathrm{E}$ and $2 \mathrm{G}$ formulations, and reported the $2 \mathrm{E}$ formulation was significantly more injurious to woody plants. Davis and Minton (1982) reported injury from application of $2 \mathrm{lb} /$ acre with the $2 \mathrm{E}$ formulation to three of 13 plant species. Over the top application of the $1.6 \mathrm{E}$ formulation to container-grown transplanted cuttings of wintercreeper euonymous (Euonymous fortunei) caused foliar injury with rates as low as $0.28 \mathrm{lb} /$ acre $\left(0.314 \mathrm{~kg} \cdot \mathrm{ha}^{-1}\right)$ a.i. (Horowitz et al., 1989). Weller et al. (1984) compared formulations in container nursery crops and reported the EC formulation to provide superior weed control but greater injury than either the granular or wettable powder formulations. Caviness et al. (1988) reported container-grown hino-crimson azalea (Rhododendronobtusum japonicum) to be more sensitive to foliar treatment than japanese holly (Ilex crenata). Generally, plants in either midsummer

Table 1. Herbicides commonly used in field nurseries, pre = preemergence, post = postemergence.

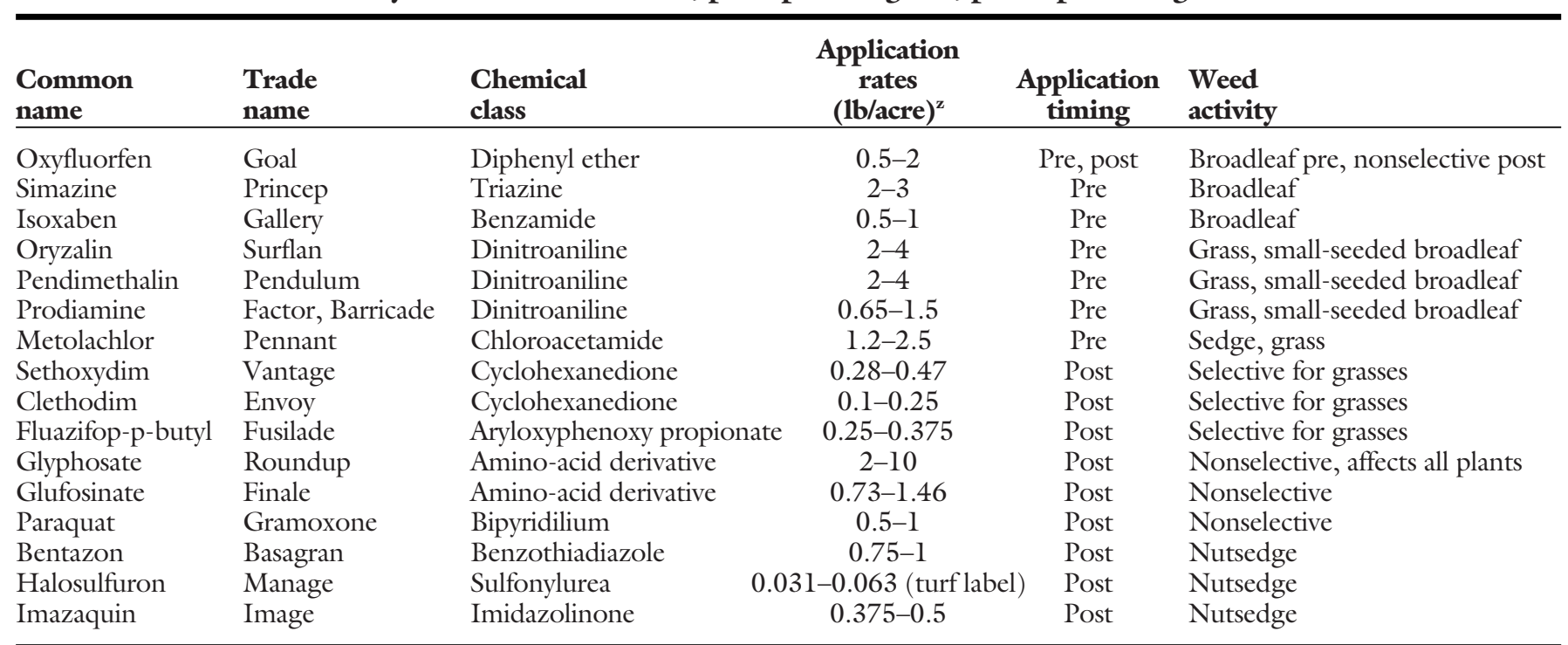

${ }^{\mathrm{z}} 1.0 \mathrm{lb} / \mathrm{acre}=1.12 \mathrm{~kg} \cdot \mathrm{ha}^{-1}$. 
dormancy or winter dormancy are more tolerant to oxyfluorfen applied over the top. Over the top application of spray-applied oxyfluorfen in early May resulted in injury to 10 species of landscape crops, with injury generally being more severe on juvenile foliage (Milbocker and Elstrodt, 1982). Gilliam et al. (1989) demonstrated that midsummer applications applied over the top of four field-grown woody crops to be noninjurious. This tolerance was attributed to a semidormant period that plants enter during environmentally stressful periods of summer. Oxyfluorfen is labeled for use on about 70 woody species, provided applications occur during winter dormancy. When nondormant applications must be made, recommendations are for directed applications to the soil and only when foliage is fully expanded and hardened (C\&P Press, 2001).

Simazine, a triazine herbicide, works as a strong inhibitor of photosynthetic electron transport (Ware, 1989). Simazine is marketed under the trade name Princep 4L [4.0 lb/gal $(0.48$ $\left.\mathrm{kg} \cdot \mathrm{L}^{-1}\right)$ a.i.], and is active against largeseeded broadleaf species. The label recommends applications at 2 to $3 \mathrm{lb} /$ acre (2.2 to $\left.3.4 \mathrm{~kg} \cdot \mathrm{ha}^{-1}\right)$ a.i., with the first application made one year after transplanting (C\&P Press, 2001). Crop tolerance to simazine is both rate and species dependent. In previous work (Wehtje et al, 1986) with field-grown littleleaf boxwood (Buxus microphylla) and red tip photinia (Photinia $\times$ fraseri), tank mixtures of oryzalin and simazine at rates up to $3+1 \mathrm{lb} /$ acre $(3.4+1.1$ $\mathrm{kg} \cdot \mathrm{ha}^{-1}$, respectively, were noninjurious yet provided a maximum degree of weed control. At the close of the 3-year study, growth indices from these treatments were either equal to or superior to the hand weeded control. Young (1980) reported a tank mixture of simazine and oryzalin $\left[2+8 \mathrm{lb} /\right.$ acre $\left.\left(2.2+9.0 \mathrm{~kg} \cdot \mathrm{ha}^{-1}\right)\right]$, applied preemergence, provided excellent $(90 \%)$ season-long control of both broadleaf and grass weeds in nonbearing peaches (Prunus persica) without causing injury. Ries et al. (1969) identified simazine as providing up to 6 weeks of weed control at either 2 or $4 \mathrm{lb} /$ acre $\left(2.2\right.$ or $\left.4.5 \mathrm{~kg} \cdot \mathrm{ha}^{-1}\right)$, with the required rate dependent on the prevalent weed species. Akers et al. (1984) reported that simazine, either alone or in combination with oryzalin, diphenamid, alachlor, or napropamide, provided sea- son-long weed control. Statistically, a tank mixture of simazine and oryzalin (1 $+4 \mathrm{lb} /$ acre) was not injurious to norway maple (Acer platanoides), creeping juniper(Juniperushorizontalis), and japanese spurge (Pachysandra terminalis). However, inspection of the data reveals that the fresh weight of these crops tended to be numerically less with this treatment relative to the nontreated control. Ryan et al. (1981) reported that preemergence applications of simazine at $6 \mathrm{lb} /$ acre $\left(6.7 \mathrm{~kg} \cdot \mathrm{ha}^{-1}\right)$ to roadside plantings were injurious to california privet (Ligustrum ovalifolium), staghorn sumac (Rhus typhina), 'Moonlight' broom (Cytisus $\times$ preaecox), and baltic ivy (Hedera helix). Ahrens (1963) reported that simazine at $3 \mathrm{lb} /$ acre was injurious to 'Lynwood Gold' forsythia (Forsythia $\times$ intermedia), weeping willow (Salix $\times$ niobi), 'Vanicek' weigelia (Weigela florida), mock orange (Philadelphus virginalis), and flowering pink almond (Prunus glanulosa). Briggs (1978) identified 2 to $3 \mathrm{lb} /$ acre as the rate of simazine necessary for weed control, and recommended that this herbicide not be used around boxwood (Buxus), euonymous (Euonymous), leucothoe (Leucothoe), nandina (Nandina), enkianthus (Enkianthus), or many of the deciduous plants, and that only low rates are safe around rhododendron (Rhododendron) species, forsythia (Forsythia), and young magnolia (Magnolia) species (exact species were not identified in the preceding reference). Bryson James, in a speech recorded by Urbano (1985), identified oryzalin plus simazine at rates up to $3+$ $1 \mathrm{lb} /$ acre, applied either in the early spring or fall, as an effective treatment for the control of annual weeds in fieldgrown ornamentals. It was recommended that this treatment be applied only once a year, otherwise an injurious buildup of simazine could result. Several other woody plant species that are simazine sensitive include catawba rhododendron (Rhododendron catawbiense), japanese andromeda (Pieris japonica) (Bing, 1981), eastern arborvitae (Thuja occidentalis) (Davis and Minton, 1982), and 'Greenspire' linden (Tilia cordata) (Smith, 1980). A more recent field study demonstrated that simazine was noninjurious to six shrub and four tree species (Setyowati et al., 1995), however, while not specifically stated, directed application was likely used instead of an over the top application.
Isoxaben, a benzamide, works by inhibiting cellulose biosynthesis in emerging seedlings (Schneegurt et al., 1994). It is marketed for field nursery crop production as a $75 \%$ active dry flowable (DF). Isoxaben is typically applied at 0.5 to $1.0 \mathrm{lb} /$ acre and provides preemergence control over a wide range of broadleaf weeds. Isoxaben is labeled for use in over 400 species. Neal and Senesac (1990) reported that isoxaben provided excellent control of many broadleaf weed species but poor annual grass control. The combination of isoxaben plus oryzalin provided an expanded spectrum of weed control with excellent safety on most container and field-grown woody nursery crops. In a previous test, isoxaben in combination with oryzalin provided weed control similar to that obtained by either oxyfluorfen or simazine when combined with oryzalin (Gilliam et al., 1989). Many nursery crops are sensitive to applications of either oxyfluorfen or simazine. And while weed control with isoxaben is no better than that provided by oxyfluorfen or simazine, the greater crop tolerance of isoxaben is an advantage where crop tolerance is marginal.

Grass-active preemergence HeRBICIDES. Oryzalin, pendimethalin (Pendulum; BASF, Research Triangle Park, N.C.), and prodiamine (Syngenta) are used for grass control in field-grown nursery crops in the southern United States. While many herbicides have been evaluated for preemergence grass control among landscape crops, these three herbicides are the most commonly used in field crop production. Trifluralin (Treflan; Lesco, Rocky River, Ohio) is another grass-active herbicides used in container nurseries; however, it is currently marketed to the nursery industry as only a granular formulation and thus is impractical for use in larger field nurseries.

Oryzalin, pendimethalin, prodiamine, and trifluralin are dinitroaniline (DNA) herbicides that act by inhibiting root formation. Oryzalin is marketed as Surflan 4AS, which is an aqueous suspension $(4 \mathrm{lb} / \mathrm{gal}$ a.i. $)$, typically applied at 2 to $4 \mathrm{lb} /$ acre a.i. Oryzalin provides excellent control of grasses and some small seeded broadleaf weeds (Gilliam et al., 1989). Surflan is labeled on over 350 woody landscape species. Application to woody field-grown nursery stock is generally noninjurious (Akers et al., 1984; Gilliam et al., 1989; Reeder et 
al., 1994). Oryzalin is commonly combined with herbicides providing preemergence-applied broadleaf weed control, such as oxyfluorfen, isoxaben, or simazine, to provide excellent broad spectrum preemergence-applied weed control (Gilliam et al., 1989; Wehtje et al., 1986; Young, 1980).

Sprayable pendimethalin is marketed under the trade name Pendulum as a $60 \%$ active water-dispersible granule (DG). Pendimethalin should be applied at 2 to $4 \mathrm{lb} /$ acre. With over 200 woody landscape plants on its label, pendimethalin is safe on field-grown stock and provides weed control similar to oryzalin and prodiamine (Reeder et al., 1994). In a study of several formulations, Pendulum 60 DG applied at 4 $\mathrm{lb} /$ acre a.i. was noninjurious when applied during the active growth stage of eastern hemlock (Tsuga canadensis), 'Plumosa' juniper (Juniperus horizontalis), yew (Taxusspp.), eastern arborvitae, border forsythia (Forsythia xintermedia) or fraser fir (Abiesfraseri); the $4 \mathrm{EC}$ formulation of pendimethalin (not commonly used in the nursery industry) was injurious to new growth of several species (Ahrens, 1988).

Prodiamine is marketed under the trade name Factor (formerly Barricade; Syngenta) in a $65 \mathrm{DG}$ formulation. Factor should be applied at 0.65 to $1.5 \mathrm{lb} /$ acre $\left(0.728\right.$ to $\left.1.68 \mathrm{~kg} \cdot \mathrm{ha}^{-1}\right)$ a.i., but the total annual amount applied should not exceed $2.3 \mathrm{lb} /$ acre (2.57 kg.ha ${ }^{-1}$ ) a.i. (C\&P Press, 2001). Factor has approximately 125 woody landscape crops on the label (some of these are not labeled for use in California). Kuhns et al. (1981) reported prodiamine at rates from 1 to $8 \mathrm{lb} /$ acre provided adequate weed control with no injury to 11 landscape species. Other field experiments evaluated prodiamine at rates from 1 to $8 \mathrm{lb} /$ acre and in each case prodiamine provided moderate to excellent weed control and no injury to landscape species (Haramaki et al., 1980; Haramaki and Kuhns, 1981; Kuhns et al., 1981; Frank, 1980).

Nutsedge-Active PreemerGence herbicides. Nutsedge is in the family Cyperaceae and is poorly controlled by the previously mentioned grass-active herbicides. Metolachlor is the most effective herbicide labeled in nursery crops for controlling nutsedge preemergence. Metolachlor, a chloroacetamide, works by retarding cell division and inhibiting meristematic growth (Ross and Lembi, 1999).
It is marketed as Pennant (Syngenta) [8 lb/gal (1.0 kg. $\left.\mathrm{L}^{-1}\right)$ a.i. ] or Pennant Magnum (Syngenta) (7.62 EC). Metolachlor provides effective control of yellow nutsedge (Cyperusesculentus) and annual grasses but poor control of broadleaf weeds (Wehtje et al., 1986; Setyowati et al., 1995). Metolachlor when applied alone or in combination with simazine at rates up to $16 \mathrm{lb} /$ acre $\left(17.9 \mathrm{~kg} \cdot \mathrm{ha}^{-1}\right)$ and $16+4 \mathrm{lb} / \mathrm{acre}$, respectively, has been reported to be noninjurious to newly planted nursery liners including: california privet, border forsythia, torringo crabapple (Malus sieboldii), red stemmed dogwood (Cornus stolonifera), japanese yew (Taxus cuspidata), andorra juniper (Juniperus horizontalis plumosa), japanese holly, red oak (Quercus borealis), eastern arborvitae, norway maple, catawba rhododendron, hino-crimson azalea, deciduous azalea (Rhododendron gandavense), and eastern hemlock (Bing, 1979). Metolachlor was noninjurious to japanese holly or wards yew (Taxus media); however, it has been reported to cause injury to ' $\mathrm{Em}$ erald N Gold' euonymous (Euonymous fortunei) (Ahrens, 1986). A separate study reported initial foliar injury to 'Hetzi' and 'Howard' holly (Ilex crenata), which was outgrown by 6 weeks after application and resulted in no suppression of plant growth or marketability (Beste and Frank, 1990).

\section{Postemergence weed control}

Grass-active herbicides. Postemergence-applied herbicides can be classified as having either selective or nonselective activity. Herbicides with selective activity used in nursery production include products with the grass-active ingredients fluazifop-butyl (Fusilade; Syngenta), sethoxydim (Vantage; BASF), or clethodim (Envoy; Valent, Walnut Creek, Calif.). These herbicides selectively control grass weeds and cause little or no injury to broadleaf plants. Fluazifopbutyl is an aryloxyphenoxy propionate. It is typically applied at 2 to $3 \mathrm{pt} /$ acre [ 0.25 to $0.375 \mathrm{lb} / \mathrm{acre}(0.280$ to $\left.0.4200 \mathrm{~kg} \cdot \mathrm{ha}^{-1}\right)$ a.i. $]$ with the addition of a nonionic surfactant. Applications should be made to actively growing grasses at a growth stage recommended by the label (C\&P Press, 2001). Fluazifop-butyl (Fusilade) is labeled on over 370 landscape species for over the top application with an additional
100 or more species labeled for directed spray applications. Sethoxydim and clethodim are cyclohexanediones. Sethoxydim is applied at 2.25 to 3.75 pt/acre [ 0.28 to $0.49 \mathrm{lb} /$ acre $(0.314$ to $0.549 \mathrm{~kg} \cdot \mathrm{ha}^{-1}$ ) a.i.] depending on grass height and species. Sethoxydim (Vantage) is labeled on over 300 woody landscape species. Clethodim (Envoy) is applied at 0.125 to $0.25 \mathrm{lb} /$ acre $\left(0.1400\right.$ to $\left.0.280 \mathrm{~kg} \cdot \mathrm{ha}^{-1}\right)$ depending on prevalent grass species and grass height. There are over 100 landscape species on its label, including 40 herbaceous crops. Applications of fluazifop-butyl and sethoxydim at rates high enough to result in $90 \%$ control of common bermudagrass (Cynodon dactylon) caused no injury to 12 species of landscape plants with the exception of 'Hexe' rhododendron (Rhododendron $\times$ 'Hexe') (Gilliam et al., 1984). Fluazifop-butyl has been tested extensively for phytotoxicity on woody plants (Bing and Macksel, 1984; Gilliam et al., 1984; Kuhns et al., 1984) and with the exception of several red flowering azalea cultivars, no phytotoxity has been reported. Over the past 3 years we have evaluated clethodim for postemergence grass control and found it provided control similar or better than sethoxydim (data unpublished).

Nonselective herbicides. Nonselective herbicides commonly used in nursery production include glufosinate (Finale; Aventis), paraquat (Gramoxone; Syngenta), and glyphosate (Roundup Pro; Monsanto, St. Louis, Mo.). These postemergence-applied herbicides should be limited to directed applications to avoid contact with nursery crops. Nonselective herbicides can be further classified as either contact or translocated. Contact herbicides only injure foliage or plant parts that are contacted by the spray, with little or no movement into noncontacted tissue. Paraquat, a bipyridilium herbicide, should be applied at 0.6 to $0.9 \mathrm{lb} /$ acre $(0.67$ to 1.01 $\left.\mathrm{kg} \cdot \mathrm{ha}^{-1}\right)$. Paraquat is a contact herbicide that provides rapid death of contacted foliage, however, it is not translocated to underground tissue, which has potential to regenerate a new shoot system. For example, paraquat provided excellent kill of purple nutsedge (Cyperus rotundus) foliage, but by 4 weeks after treatment regrowth from roots had occurred (Wooten and Neal, 2000). Thorough coverage is necessary for obtaining control, therefore 
higher spray volumes are recommended. Paraquat is a restricted use herbicide due to its acute mammalian toxicity $\left[\right.$ oral $\left.\mathrm{LD}_{50}=150 \mathrm{ppm}\left(\mathrm{mg} \cdot \mathrm{kg}^{-1}\right)\right]$, therefore care should be used in mixing and applying the herbicide. Glufosinate, an amino acid derivative, is also a contact herbicide and is applied at rates of 4 to $6 \mathrm{qt} /$ acre [ 1.0 to $1.5 \mathrm{lb} /$ acre (1.12 to $\left.\left.1.68 \mathrm{~kg} \cdot \mathrm{ha}^{-1}\right)\right]$. Glufosinate is far less toxic to mammals (oral $\mathrm{LD}_{50}=$ $2000 \mathrm{ppm}$ ) than paraquat, and thus can be used in similar situations to paraquat with less chance of injury to the applicator.

Translocated herbicides are absorbed by plant parts that make contact with the spray and are moved throughout the root and shoot system. Translocated herbicides are effective in providing control of perennial weeds with well-developed root systems. Glyphosate is a translocated herbicide that provides control over a broad spectrum of weeds and is commonly used in the nursery industry. A problem frequently encountered in nursery production is use of improper glyphosate rates. For annual weeds less than 6 inches $(15.2 \mathrm{~cm})$ in height glyphosate should be applied as a $1 \%$ solution, and for weeds greater that 6 inches in height glyphosate should be applied at a $1.5 \%$ solution (Gilliam, 1989). For perennial weeds, a $3 \%$ to $5 \%$ solution should be used. Improper application of glyphosate causes more injury to nursery crops than any other herbicide used. The label recommends avoiding contact of spray, drift, or mist with foliage or green bark of landscape crops (C\&P Press, 2001). However, studies have shown that several landscape crops, including lily-turf (Liriope muscari), 'Burford' holly (Ilex cornuta), 'Rotunda' holly (I. cornuta), dwarf yaupon holly (I. vomitoria), harland boxwood (Buxus harlandii), chinese privet (Ligustrum sinense), variegated waxleaf privet (L. lucidum), 'Recurvifolium' privet (L.japonicum), heavenly bamboo (Nandina domestica), and others have tolerance to low rates of glyphosate (Self, 1974; Self and Washington, 1977). Longterm injury was not reported from these experiments, so caution should be used before relying on their safety claims.

Nutsedge-ACtive herbicides. Herbicides used specifically for postemergence nutsedge control include bentazon (Basagran, BASF), halosulfuron (Manage, Monsanto), and imazaquin (Image, BASF). Yellow nutsedge is considered to be one of the most troublesome weeds in the world. Yellow nutsedge propagates by seed and tubers. A single tuber of yellow nutsedge is capable of producing about 7000 new tubers and 1900 new aerial shoots in one season (Tumblesome and Kommedahl, 1961). Cultivation or mechanical removal of yellow nutsedge often leads to spreading the tubers throughout the nursery and is therefore an ineffective control method (Wilcut et al., 1991). Container studies have demonstrated effective yellow nutsedge control using rates of bentazon, a benzothiadiazole, from 1.5 to $6.0 \mathrm{lb} /$ acre (1.68 to $6.72 \mathrm{~kg} \cdot \mathrm{ha}^{-1}$ ) (Fretz and Sheppard, 1978). Injury due to over the top applications of bentazon is species dependent (Wilson and Whitwell, 1993) and appears to be related to the ability of different species to metabolize bentazon into nonphytotoxic metabolites. Nonetheless, over the top applications have proven injurious to a variety of landscape crops (Bachman et al., 1995; Wilson and Whitwell, 1993), therefore directed applications in the field are recommended.

Two container studies have demonstrated that imazaquin (an imidazolinone) and halosulfuron (a sulfonylurea) provide effective postemergence control of yellow and purple nutsedge (Hurt and Vencill, 1994a, 1994b) with control from halosulfuron being slightly better. However, since both products may cause injury with over the top applications, directed applications are recommended.

A recent study on postemergence purple nutsedge control demonstrated that two applications of halosulfuron or imazaquin provided effective control in the same year they were applied; however, control did not carry over into the next year (Wooten and Neal, 2000). In the same study, late season application of glyphosate and glufosinate provided the most effective control through the year following application, suggesting the late post applications significantly reduced tuber formation or tuber viability.

A carefully planned weed management strategy for weed control in field production and landscape environments should include knowledge of the following: weed biology, herbicide application and calibration procedures, herbicide efficacy against target weeds, landscape and nursery crop tolerance to herbicides applied, and correct timing of applications. Information in this manuscript provides growers with a current list of herbicides and their properties to aid them in selecting the most appropriate herbicides for successful weed control in field nurseries.

\section{Literature cited}

Ahrens, J.F. 1963. Chemical control of weeds in deciduous nursery plantings. Proc. N.E. Weed Control Conf. 17:208-212.

Ahrens, J.F. 1986. Fall vs. spring applied herbicides in Taxus. Proc. N.E. Weed Sci. Soc. 40:249-252.

Ahrens, J.F. 1988. Herbicides for fieldgrown woody ornamentals. Proc. N.E. Weed Sci. Soc. 42:128.

Akers, M.S., P.L. Carpenter, and S.C. Weller. 1984. Herbicide systems for nursery plantings. HortScience 19:502-504.

Bachman, G., C. Wilson, and T. Whitwell. 1995. Tolerance of containerized landscape plants to the postemergence herbicides Stinger, Manage and Basagran. J. Environ. Hort. 13:129-132.

Berchielli-Robertson, D.L., C.H. Gilliam, and D.C. Fare. 1990. Competitive effects of weeds on the growth of container-grown plants. HortScience 25:77-79.

Beste, C.E. and J.R. Frank. 1990. Influence of metolachlor on Ilex crenata Thunb. for control of yellow nutsedge. J. Environ. Hort. 8:58-60.

Bing, A. 1979. Results with postplant Preemergence herbicide treatments on nursery liners. Proc. N.E. Weed Control Conf. 23:309-314.

Bing, A. 1981. 1980 preemergence weed control in nursery liners. Proc. N.E. Weed Sci. Soc. 35:235-239.

Bing, A. and M. Macksel. 1984. Postemergence applications of fluazifopbutyl an sethoxydim on azaleas. Proc. N.E. Weed Sci. Soc. 38:251-252.

Briggs, B.A. 1978. Getting the most out of herbicides. Proc. Intl. Plant Prop. Soc. 28:89-93.

C\&P Press. 2001. Turf and ornamental reference, p. 562. C\&P Press, New York.

Caviness, D.M., R.E. Talbert, and G.L. Klingman. 1988. Chemigation and spray application of herbicides on containergrown ornamentals. Weed Technol. 2:418422 . 
Coffman, C.B., J.R. Frank, and W.A. Gentner. 1984. Sethoxydim (Poast) and oxyfluorfen (Goal) efficacy and tolerance by landscape plants. J. Environ. Hort. 2:120-122

Coffman, C.B. and J.R. Frank. 1987. Weed management with fluazifop (Fusilade), haloxyfop (Verdict), sethoxydim (Poast) and oxyfluorfen (Goal) in groundcovers and woody landscape plants. J. Environ. Hort. 5:85-88.

Davis, G. and R. Minton. 1982. Herbicide efficacy and phytotoxicity of thirteen selection from Euonymous, Juniperus, Taxus, Thuja, Viburnum, Magnolia and Ilex. Proc. S. Nursery Assn. Res. Conf. 27:272-277.

Frank, J.R. 1980. Nursery weed control with oxyfluorfen, prodiamine, oryzalin, glyphosate, and paraquat. HortScience 15(3):413 (abstr).

Fretz, T.A. and W.J. Sheppard. 1978. Yellow nutsedge control in container-grown nursery stock with bentazon. Ornamental plants-1978. A summary of research. Ohio State Univ. Agr. Res. Dev. Ctr.

Fretz, T.A, J.J. Koncal, and W.J. Sheppard. 1980. Evaluation of oxyfluorfen for weed control and phytotoxicity on container grown nursery stock. Ornamental plants1980. A summary of research. Ohio State Univ. Agr. Res. Dev. Ctr.

Gilliam, C.H., J.S. Crockett, and C. Pounders. 1984. Bermudagrass control in woody ornamentals with postemergence-applied herbicides. HortScience 19:107-109.

Gilliam C.H. 1989. On the way to weedfree fields. Amer. Nursery 169:65-66.

Gilliam, C.H., G. Wehtje, J.E. Eason, T.V. Hicks, and D.C. Fare. 1989. Weed control with Gallery and other herbicides in fieldgrown nursery crops. J. Environ. Hort. 7:69-72.

Haramaki, C., L. Kuhns, and D. Grenoble. 1980. Preemergent weed control in ornamental liner beds. Proc. N.E. Weed Sci. Soc. 34:320-323.

Haramaki, C. and L. Kuhns. 1981. Preemergent herbicides on newly planted liners. Proc. N.E. Weed Sci. Soc. 35:240244.

Horowitz, M., C.L. Elmore, and D.
Boquist. 1989. Directed applications of Goal (oxyfluorfen) to container-grown Euonymous to minimize phytotoxity and leaching. J. Environ. Hort. 7:17-21.

Hurt, R.T. and W.K. Vencill. 1994a. Evaluation of three imidazolinone herbicides for control of yellow and purple nutsedge in woody and herbaceous landscape plants. J. Environ. Hort. 12:131-134.

Hurt, R.T. and W.K. Vencill. 1994b. Phytotoxicity and nutsedge control in woody and herbaceous landscape plants with Manage (MON12037). J. Environ. Hort. 12:135-137.

Kuhns, L., C. Haramaki, and J. Staub. 1981. Preemergence herbicides on established ornamental liners. Proc. N.E. Weed Sci. Soc. 35:245.

Kuhns, L.J., G. Twerdok, and C. Haramaki. 1984. Screening woody ornamentals for tolerance to fluazifop-butyl and sethoxydim. Proc. N.E. Weed Sci. Soc. 38:254-255.

Milbocker, D.C. and C.J. Elstrodt. 1982. Using oxyfluorfen, Goal, in the nursery. Proc. S. Nursery Res. Conf. 27:285-286.

Neal, J.C. and A.F. Senesac. 1990. Preemergent weed control in container and fieldgrown woody nursery crops with Gallery. J. Environ. Hort. 8:103-107.

Reeder, J.A., C.H. Gilliam, G.R. Wehtje, D.B. South, and G.J. Keever. 1994. Evaluation of selected herbicides on field-grown woody ornamentals. J. Environ. Hort. 12:236-240.

Ries, S.K., B.H. Grisby, H. Davidson. 1969. Evaluation of herbicides on several species of ornamentals. Weeds 7:409-417.

Ross, M.A. and C.A. Lembi. 1999. Applied weed science. $2^{\text {nd }}$ ed. Prentice Hall, Upper Saddle River, N.J.

Ryan, G.F., R.N. Rosenthan, and R.L. Berger. 1981. Napropamide and oryzalin effect on simazine tolerance of four ornamental species. Weed Sci. 29:329-332.

Schneegurt, M.A., J.L. Roberts, L.A. Bjelk, and B.C. Gerwick. 1994. Postemergence activity of isoxaben. Weed Technol. 8:183189.

Self, R.L. 1974. Screening tests with glyphosate on woody ornamentals. Proc. S. Nursery Res. Conf. 19:118-119.

Self, R.L. and O. Washington. 1977. Overthe-top application of Roundup to rooted cuttings, liners, and pot-grown woody ornamentals. Proc. S. Nursery Res. Conf. 22:175-176.

Setyowati, N., L.A. Weston, and R.E. McNiel. 1995. Evaluation of selected preemergence herbicides in field-grown landscape crops in Ky. J. Environ. Hort. 13:196-202.

Smith, E.M. 1980. Tolerance of Greenspire littleleaf linden to herbicides. Ohio Agr. Res. Dev. Res. Circ. 253:35-36.

Tumblesome, M.E. and T. Kommedahl. 1961. Reproductive potential of Cyperus esculentus by tubers. Weeds 9:646-653.

Urbano, C.C. 1985. Some recommended herbicides and rates for effective weed control. Amer. Nursery 16:87-88.

Ware, G.W. 1989. The pesticide book. Thompson Publications, Fresno, Calif.

Wehtje, G. and C.H. Gilliam. 1991. Weed control in field-grown holly. J. Environ. Hort. 9:29-32.

Wehtje, G., C. Gilliam, T. Whitwell, C. Pounders, and W. Webster. 1986. Weed control in field-grown boxwood and photinia. HortScience 21:445-448.

Weller, S.C., J.B. Masiunas, and P.L. Carpenter. 1984. Evaluation of oxyfluorfen formulations in container nursery crops. HortScience 19:222-224.

Wilcut, J.W., C.H. Gilliam, G.R. Wehtje, T.V. Hicks, and D.L Berchielli. 1991. Yellow nutsedge control in landscape plants. HortScience 26:159-162.

Wilson, C. and T. Whitwell. 1993. Tolerance of nineteen species of container grown landscape plants to postemergence applications of Basagran. J. Environ. Hort. 11:86-89.

Wooten, R.E. and J.C. Neal. 2000. Postemergent control of purple nutsedge (Cyperus rotundus L.). Proc. S. Nursery Res. Conf. 45:341-343.

Young, R.S. 1980. Oryzalin-simazineparaquat for peach trees. Proc. N.E. Weed Sci. Soc. 34:299. 